\title{
Editorial
}

\section{| El cine de Sergio Navarro |}

Este número especial de Revista Márgenes está dedicado al trabajo cinematográfico de Sergio Navarro, Profesor de la Universidad de Valparaíso, quien dirigió y re-fundó la Escuela de Cine de la Universidad de Valparaíso. Comprometido siempre con el cine, su labor se concentra en tres ejes o aristas: el de la pedagogía, la investigación y la realización. En el primero, numerosas voces pueden dar cuenta de los conocimientos impartidos y el compromiso con la sala de clases, dejando impresiones no sólo en el mundo de los y las estudiantes, sino también, y con igual energía, en el de las y los profesores. En el campo de la investigación destacan varias publicaciones, gran parte de ellas dedicadas a profundizar el cine de Raúl Ruiz. En el campo de la realización, al cual este número de Revista Márgenes se consagra, Sergio Navarro creó varias piezas interesantes que se inscriben, ciertamente, en la historia del cine nacional, si bien, por diversos motivos, han pasado desapercibidas o poco atendidas.

En este sentido, este número de Revista Márgenes busca resaltar su cinematografía e indagar en algunas de estas piezas. Sergio Navarro es heredero directo de la generación del 60, aprende y proyecta ese conocimiento, se convierte en cuerpo y testimonio de esta historia del cine chileno. Une varias generaciones, por lo tanto, varias miradas, varios enfoques. Por ello fue capaz de ver, por ejemplo, antes que cualquier ojo cinematográfico, 
la precarización radical que instaló la dictadura en las poblaciones de Santiago, destruyendo el pasado creativo y asociativo que esas poblaciones no solo representaban, sino habían levantado a través de la organización y la solidaridad. Caminito al cielo (1989) observa la realidad que nos dejaba uno de los periodos más oscuros de la historia nacional, y lo hace casi de inmediato, con una capacidad de observación que se revela siempre abierta y atenta, nunca extraviada.

En las siguientes páginas se podrán apreciar análisis, reconsideraciones, observaciones, entre otros, de diversas piezas de Sergio Navarro. Tiziana Panizza, Iván Pinto, Héctor Oyarzún, Catalina Donoso y el mismo Sergio Navarro abren un trabajo de comprensión de esta historia cinematográfica, siendo un honor para Revista Márgenes poder albergar y difundir estas páginas.

Asimismo, esperamos que esta iniciativa abra posteriores trabajos de indagación en la obra de Navarro, la cual, insistimos, tiene vida propia en la historia de la realización en Chile en la medida que busca y rodea, incansablemente, la idea de cine $\mathrm{o}$, al menos, una entre ellas, siempre interesante y verdadera.

GUSTAVO CELEDÓN BÓRQUEZ

EDITOR 